\title{
Bioclogging in porous media: influence in reduction of hydraulic conductivity and organic contaminants during synthetic leachate permeation
}

\author{
Subramaniam Kanmani, Rajan Gandhimathi ${ }^{*}$ and Kasinathan Muthukkumaran
}

\begin{abstract}
In this study the concept of biofilm accumulation in the sand column was promoted to assess the changes in hydraulic conductivity and concentration of organic contaminants of the synthetic leachate. Four different combinations of column study were carried out using synthetic leachate as a substrate solution. Mixed and stratified mode of experiments with two different sizes $(0.3 \mathrm{~mm}$ and $0.6 \mathrm{~mm})$ of sand grains were used for column filling. Two columns were acting as a blank, the remaining two columns amended with mixed microbial cultures which were isolated from leachate. The column was operated with continuous synthetic leachate supply for 45 days. The results indicated that the highest hydraulic conductivity reduction occurred in the mixed sand microbial column with $98.8 \%$ when compared to stratified sand microbial column. The analysis of organic contaminants of the effluent leachate was also clearly shown that the mixed sand amended with microbes poses a suitable remedial measure when compared to natural and synthetic liners for controlling the leachate migration in the subsurface environment.
\end{abstract}

Keywords: Biofilm, Hydraulic conductivity, Microbial culture, Synthetic leachate

\section{Introduction}

The generation of solid waste has become an increasing environmental and public health problem everywhere in the universe, especially in the developing countries [1]. Open dumps are the oldest and the most common mode of disposing of solid waste. Although in recent years, thousands have been closed, many still are being used [2]. The dumping of solid waste in uncontrolled landfills can have significant impacts on the environment and human health [3]. Leachate migrations from waste sites or landfills and the release of pollutants from sediment (under certain conditions) pose a high risk to groundwater resource if not adequately managed. Plenty of materials have been identified as contaminants of ground water. These include synthetic organic chemicals, hydrocarbons, inorganic cations, inorganic anions, pathogens, and radio nuclides. Most of these materials dissolve in

\footnotetext{
*Correspondence: rgmathii@nitt.edu

Department of Civil Engineering, National Institute of Technology, Tiruchirappalli, Tamilnadu, India
}

water to varying degrees [4]. Their impact on groundwater continues to raise concern and have become the subject of recent and past investigations [5-15].

Continuously increasing awareness in preserving the groundwater supplies from contaminants generated from waste sites has given rise to the design of well-isolated containment structures. These measures generally involve the application of low permeability natural clays and sandbentonite mixtures or synthetic materials [16]. Compacted natural clays are often used in constructing hydraulic barriers underneath waste containment systems. The hydraulic conductivity must be less than or equal to $1 \times$ $10^{-7} \mathrm{~cm} / \mathrm{s}$ for soil liners and covers used to contain hazardous waste, industrial waste, and municipal waste [17]. In the absence of impervious natural clay liners, Geosynthetic Clay Liners (GCLs) are progressively being employed as constituent of a composite liner with geomembranes (GM) in landfill barrier systems [18]. The primary advantages of the GCL are the limited thickness, the good compliance with differential settlements of the 
underlying ground or waste, easy installation and low price. On the other hand, the limited thickness of this barrier can produce: (1) vulnerability to mechanical accidents, (2) limited sorption capacity, and (3) an expected significant increase of diffusive transport if an underlying attenuation mineral layer is not provided [19]. Exothermic degradation of organic matter or hydration of incinerator ash within the landfill generates heat inside the waste pile. This creates thermal gradients through the composite liner, which hold the potential to cause a net movement of moisture away from the warmer liner. The result is a potential for desiccation that may impair the long-term performance of the GCL [20]. As the role of the GCLs broadens, they are being investigated intensively, particularly in respect to their hydraulic and diffusion characteristics, chemical compatibility, mechanical behavior, durability and gas migration [21-30]. These methods have proved to be expensive and, in many cases, ineffective at achieving the proposed level of cleanup. The biofilm accumulation in the porous media is an effective way in the reduction of hydraulic conductivity and concentration of organic contaminants from the leachate. This technique stimulates the microbes to remove subsurface pollutants, which is prominent because it has the potential to: permanently eliminate the contaminants through biochemical transformation or mineralization; avoid harsh chemical and physical treatments; operate in situ and be cost effective [31,32]. Aquifer material is excavated and replaced with microbial cultures as horizontal treatment layers and as vertical treatment walls. These engineered biofilm layers eliminate the contaminants on in-situ transformations [33]. Among the various contaminated groundwater remediation measures that consider results, risks, and costs, biofilm accumulation is preferred [34].

A biofilm is a well organized, cooperating community of microorganisms. Microbial cells attach to the surfaces and develop a biofilm. Biofilm associated cell is differentiated from suspended counterparts by reduced growth rate, upwards and down regulation of gene and generation of extra polymeric substances [35]. Genetic studies have revealed that biofilms are formed through multiple steps. They require intracellular signalling and transcribe different set of genes from planktonic cell [36]. Biofilm accumulation in porous media is the overall result of microbial cell adsorption, desorption, growth on surfaces, detachment and filtration. The microbial growth in land and the resultant decrease in hydraulic conductivity are much connected with groundwater recharge, wastewater, soil injection, enhanced oil recovery schemes, and the in situ bioremediation of organic contaminants in the subsurface environment [37].

A turn of previous experiments have looked into the issue of microbial biomass growth on reduction of porosity, permeability and hydraulic conductivity in porous media $[38-41,37,42,43]$ and rock-fracture analogues [41,44] which could induce an outcome on the fate of contaminants in the subsurface.

Seki et al. [45] concluded that bacterial clogging proceeds more rapidly than fungal clogging probably because bacteria grow faster than fungi on the ground surface. Taylor and Jaffe [38] conducted experiments on sand packed column reactors to study the issue of biomass growth on soil permeability and dispersivity using methanol as a growth substrate. From the answers, the permeability reduction was noted by three orders of magnitude. Vandevivere and Baveye [40] and Bielefeldt et al. [46] estimated the hydraulic conductivity reductions of three orders of magnitude. Cusack et al. [47] reported that the decrease in $\mathrm{K}$ (hydraulic conductivity) was achieved as $99 \%$ in sandstone by using starved bacteria. Cunningham et al. [39] used sand (grain size: $0.54 \mathrm{~mm}$ and $0.12 \mathrm{~mm}$ ) column inoculated with bacteria and applied a constant head difference between inflow and outflow. A reduction of more than $90 \%$ in hydraulic conductivity and $50-90 \%$ in porosity was observed. Brough et al. [48] noted a reduction of hydraulic conductivity of between 28 and $79 \%$ using 35 series of column experiment.

Kim [49] evaluated the changes in hydraulic conductivity as $1 \times 10-4 \mathrm{~cm} / \mathrm{Sec}$ is using sand columns (sand grains of 0.25 millimeter to $0.42 \mathrm{~mm}$ in size) due to barrier formation. Kim et al. [37] reported the hydraulic conductivity reduction by $1 / 8000$ of the initial hydraulic conductivity when the uninterrupted provision of substrate and oxygen. Zhong and Wu et al. [34] investigated the bioclogging in porous media (sand grains of size $0.2 \mathrm{~mm}$ to $0.5 \mathrm{~mm}$ ) under continuous flow condition and achieved the hydraulic conductivity reduction in one order magnitude. Several authors reported a significant reduction of hydraulic conductivity due to bioclogging. These studies demonstrated that the biobarrier may be a promising technology for containing contaminant plume in the field. Improved understanding of these interactions will lead to industrial and environmental applications in bio hydrometallurgy, enhanced oil recovery, and bioremediation of contaminated groundwater and soil [39].

In this research study, the influence of biofilm accumulation using sand column is described by (1) the reduction in hydraulic conductivity of the inoculated microbial sand column (2) the physico-chemical characteristic of the effluent leachate such as $\mathrm{pH}$, turbidity, total dissolved solids (TDS), oxidation reduction potential (ORP), nitrates, phosphates and degradation of organic contaminants in terms of COD.

\section{Materials and methods \\ Sand}

Sand used in this study was collected from a river shore Cauvery, which is located in the Trichirappalli district, 
Tamilnadu. The physical properties of the sand were determined as per the code IS 2720: 1987 [50] and are presented in Table 1. Sand thus collected were sieved, the portions which retained on $0.6 \mathrm{~mm}$ and $0.3 \mathrm{~mm}$ were washed with distilled water, cooled to room temperature and preserved in clean plastic containers for subsequent use. Sand samples were sterilized in an autoclave before microorganisms were inoculated.

\section{Chemicals}

All the chemicals used in this study were of analytical reagent (AR) grade and were supplied by Merck specialities Ltd., Mumbai, India. Glassware used for analysis was washed with an acid solution followed by distilled water.

\section{Isolation of microorganism}

In this study, bacterial strains were isolated from the leachate samples collected from an open dumping site at Ariyamangalam, Tiruchirappalli, Tamilnadu. To eliminate the target contaminants from the leachate, the experimental microorganisms were isolated from leachate sample according to normal microbiological procedures. The nutrient medium (NM) for bacterial growth consists of Peptone (10 g), Beef extract (2 g), Yeast extract (1 g), and Sodium Chloride (5 g) in $1 \mathrm{~L}$ of distilled water [51]. The $\mathrm{pH}$ was maintained at $7 \pm 0.2$ through the addition of $\mathrm{HCl}$ $(0.1 \mathrm{~N})$ or $\mathrm{NaOH}(0.1 \mathrm{~N})$. The media were sterilized by wet autoclaving at $15 \mathrm{kPa}$ and $121^{\circ} \mathrm{C}$ for $20 \mathrm{~min}$. Approximately $10 \mathrm{ml}$ of leachate was added to $100 \mathrm{ml}$ of nutrient medium (NM) and incubated for $48 \mathrm{~h}$ at $37^{\circ} \mathrm{C}$ in facultative condition [52]. The shake flask cultures were closed using Teflon stoppers.

The growth rate of the microorganisms was estimated by measuring Optical Density (OD), defined as the logarithmic ratio of the initial light intensity to the light intensity not disturbed by the microorganisms. OD can be measured by using a spectrophotometer at $600 \mathrm{NM}$ wavelengths [53]. A loopful of incubated mixed culture was streaked on agar slants, incubated for $24 \mathrm{~h}$ and stored in the freezer at $4^{\circ} \mathrm{C}$ for further use.

\section{Bacterial cultivation in synthetic leachate}

The substrate solution used in this column study was synthetic leachate (Table 2) [54]. It consists of three

Table 1 Physical properties of sand

\begin{tabular}{lll}
\hline S. No & Properties & Value \\
\hline 1. & Specific gravity & 2.65 \\
2. & Porosity & 0.33 \\
3. & Permeability $(\mathrm{cm} / \mathrm{sec})$ & $1 \times 10^{-1}$ \\
4. & Dry density $\left(\mathrm{g} / \mathrm{cm}^{3}\right)$ & 1.950 \\
5. & Organic content $(\%)$ & 0.177 \\
6. & Moisture content $(\%)$ & 0.049 \\
\hline
\end{tabular}

Table 2 Composition of synthetic leachate

\begin{tabular}{|c|c|c|}
\hline S. No. & Component & Quantity per litre \\
\hline 1. & Acetic acid & $7 \mathrm{ml}$ \\
\hline 2. & Propionic acid & $5 \mathrm{ml}$ \\
\hline 3. & Butyric acid & $1 \mathrm{ml}$ \\
\hline 4. & $\mathrm{~K}_{2} \mathrm{HPO}_{4}$ & $30 \mathrm{mg}$ \\
\hline 5. & $\mathrm{KHCO}_{3}$ & $312 \mathrm{mg}$ \\
\hline 6. & $\mathrm{~K}_{2} \mathrm{CO}_{3}$ & $324 \mathrm{mg}$ \\
\hline 7. & $\mathrm{NaCl}$ & $1440 \mathrm{mg}$ \\
\hline 8. & $\mathrm{NaNO}_{3}$ & $50 \mathrm{mg}$ \\
\hline 9. & $\mathrm{NaHCO}_{3}$ & $3012 \mathrm{mg}$ \\
\hline 10. & $\mathrm{CaCl}_{2}$ & $2882 \mathrm{mg}$ \\
\hline 11. & $\mathrm{MgCl}_{2} 6 \mathrm{H}_{2} \mathrm{O}$ & 3114 mg \\
\hline 12. & $\mathrm{MgSO}_{4}$ & $156 \mathrm{mg}$ \\
\hline 13. & $\mathrm{NH}_{4} \mathrm{HCO}_{3}$ & $2439 \mathrm{mg}$ \\
\hline 14. & $\mathrm{CO}\left(\mathrm{NH}_{2}\right)_{2}$ & $695 \mathrm{mg}$ \\
\hline 15. & $\mathrm{Na}_{2} \mathrm{~S} \cdot 9 \mathrm{H}_{2} \mathrm{O}$ & Titrate to an Eh $120 \mathrm{mV}: 180 \mathrm{mV}$ \\
\hline 16. & $\mathrm{NaOH}$ & Titrate to a pH 5.8-6.0 \\
\hline 17. & Trace metal solution (TMS) & $1 \mathrm{ml}$ \\
\hline 18. & Distilled Water & To make 11 \\
\hline \multicolumn{3}{|c|}{ Composition of trace metal solution (TMS) } \\
\hline 1. & $\mathrm{FeSO}_{4}$ & $2000 \mathrm{mg}$ \\
\hline 2. & $\mathrm{H}_{3} \mathrm{BO}_{4}$ & $50 \mathrm{mg}$ \\
\hline 3. & $\mathrm{ZnSO}_{4} \cdot 7 \mathrm{H}_{2} \mathrm{O}$ & $50 \mathrm{mg}$ \\
\hline 4. & $\mathrm{CuSO}_{4} \cdot 5 \mathrm{H}_{2} \mathrm{O}$ & $40 \mathrm{mg}$ \\
\hline 5. & $\mathrm{MnSO}_{4} \cdot 7 \mathrm{H}_{2} \mathrm{O}$ & $500 \mathrm{mg}$ \\
\hline 6. & $\left(\mathrm{NH}_{4}\right)_{6} \mathrm{Mo}_{7} \mathrm{O}_{24} \cdot 4 \mathrm{H}_{2} \mathrm{O}$ & $50 \mathrm{mg}$ \\
\hline 7. & $\mathrm{Al}_{2}(\mathrm{SO})_{3} \cdot 16 \mathrm{H}_{2} \mathrm{O}$ & $30 \mathrm{mg}$ \\
\hline 8. & $\mathrm{CoSO}_{4} .7 \mathrm{H}_{2} \mathrm{O}$ & $150 \mathrm{mg}$ \\
\hline 9. & $\mathrm{NiSO}_{4} \cdot 6 \mathrm{H}_{2} \mathrm{O}$ & $500 \mathrm{mg}$ \\
\hline 10. & $96 \%$ concentration $\mathrm{H}_{2} \mathrm{SO}_{4}$ & $1 \mathrm{ml}$ \\
\hline 11. & Distilled Water & To make 1 I \\
\hline
\end{tabular}

volatile fatty acids with various salts and a trace metal solution. The physical and chemical characteristics of the synthetic leachate were analyzed as per standard methods [55] and are presented in Table 3. Synthetic leachate was made in bulk and refrigerated for further

Table 3 Physicochemical characteristics of synthetic leachate

\begin{tabular}{lll}
\hline S. No. & Parameters & Value \\
\hline 1. & $\mathrm{pH}$ & 6 \\
2. & Turbidity in NTU & 1 \\
3. & Total Dissolved Solids (TDS) in $\mathrm{mg} / \mathrm{L}$ & 13000 \\
4. & Nitrates $\left(\mathrm{NO}_{3}^{-}\right)$in $\mathrm{mg} / \mathrm{L}$ & 3.5 \\
5. & Phosphates $\left(\mathrm{PO}_{4}^{3-}\right)$ in $\mathrm{mg} / \mathrm{L}$ & 27 \\
6. & Chemical Oxygen Demand (COD) in $\mathrm{mg} / \mathrm{L}$ & 14000 \\
\hline
\end{tabular}


usage. Chemical Oxygen Demand (COD) of the synthetic leachate was measured at $14000 \mathrm{mg} / \mathrm{L}$ using the closed reflux method. $40 \mathrm{ml}$ of isolated mixed bacterial culture was transplanted to $400 \mathrm{ml}$ of synthetic leachate solution contains $14,000 \mathrm{mg} / \mathrm{L}$ of COD [52]. This culture was incubated aerobically at $27^{\circ} \mathrm{C}$ on a $125-\mathrm{RPM}$ orbital shaker for 7 days. Aerobic conditions were utilized to quickly generate biomass for sand column experiments because the microbial species of interest are facultative [56]. During the microbial growth, the increase in MLSS concentration was assessed with the reduction in COD concentration. Steady state COD concentration was noted in seven days with the microbial count of $340 \times 105$ cells/cc. The developed microbial biomass solution was used for filling the experimental column.

\section{Experimental setup}

A column study was carried out to understand the changes in the reduction of hydraulic conductivity and organic contaminants of the effluent leachate due to the biofilm accumulation. Four identical columns made of glass with a diameter of $2.5 \mathrm{~cm}$ and a length of $35 \mathrm{~cm}$ was used for the study. Figure 1 shows the schematic representation of the experimental set-up. The column was fabricated using gas-leak-proof materials and parts. Synthetic leachate was supplied as a substrate solution throughout the study.

The cleaned sand of size $0.6 \mathrm{~mm}$ and $0.3 \mathrm{~mm}$ were used for filling each column. A mixture of $70 \%$ of $0.3 \mathrm{~mm}$ sand and $30 \%$ of $0.6 \mathrm{~mm}$ sand, by weight (70:30 mix) were used for filling the first two columns. Column 1 was filled with mixed sand media (MSM); whereas column 2 was amended with microbes in mixed sand media (MSMM). The other two columns were filled with stratified layer of sand media such as, $110 \mathrm{~g}$ of $0.3 \mathrm{~mm}$ sand in the top layer $(0-15 \mathrm{~cm})$ and $100 \mathrm{~g}$ of $0.6 \mathrm{~mm}$ sand in the bottom layer $(15-30 \mathrm{~cm})$. Column 3 was filled with sand media in stratified mode (SSM); whereas column 4 was amended with microbes in stratified sand media (SSMM). Totally, 210 grams of sand media were weighed and packed for a depth of $30 \mathrm{~cm}$ of each column. Column 1 and 3 were used as a blank, without any addition or inoculation. To inoculate the columns 2 and $4,80 \mathrm{ml}$ of developing a culture containing approximately $340 \times 10^{5}$ cells $/ \mathrm{ml}$ were mixed with $210 \mathrm{~g}$ of sterilized sand, and the resulting slurry was aseptically poured into the columns. The inoculated sand columns were incubated under no-flow conditions for $24 \mathrm{~h}$, to promote bacterial attachment to the sand [57]. Glass wools were placed at the outlet of the each column to retain the sand in the columns. The experiments were carried out at a temperature of $20 \pm 1^{\circ} \mathrm{C}$ and the sand-bed columns were side protected from the light [58].
The synthetic leachate described previously was fed to the inlet tank, which can be located at the preferred height. The overflow was circulated to the inlet tank to maintain a constant hydraulic head. The $\mathrm{pH}$ of the synthetic leachate was adjusted as 5.8 to 6.0 throughout the experimental study. A four channel peristaltic pump was set to distribute a constant flow of $1 \mathrm{ml} / \mathrm{min}$ synthetic leachate for a combined flow rate of $4 \mathrm{ml} / \mathrm{min}$. volumetric flow rates were monitored frequently. To begin with, the outlet flow rate was also set at $1 \mathrm{ml} / \mathrm{min}$ for all the columns. Saturated conditions in the columns were kept by controlling the water surface $5 \mathrm{~cm}$ above the sand-bed.

The hydraulic conductivity was measured as a function of time in each column using the constant head method based on ASTM D 2434 [59]. Hydraulic conductivity was calculated using Darcy's law, as follows:

$$
K=Q L / A \times t \times h
$$

Where,

$$
\begin{aligned}
& \text { K - hydraulic conductivity }(\mathrm{cm} / \mathrm{s}) \\
& \text { Q - volume of flow }\left(\mathrm{cm}^{3}\right) \\
& \text { L - length specimen }(\mathrm{cm}) \\
& \text { A - cross sectional specimen area }\left(\mathrm{cm}^{2}\right) \\
& \mathrm{t} \text { - time during which Q occurs }(\mathrm{s}) \text { and } \\
& \text { h - hydraulic head }(\mathrm{cm})
\end{aligned}
$$

The effluent samples were collected daily from the outlet port of the each column and the physicochemical parameters such as $\mathrm{pH}$, turbidity, Total Dissolved Solids (TDS), Nitrates $\left(\mathrm{NO}_{3}^{-}\right)$, Phosphates $\left(\mathrm{PO}_{4}^{3-}\right)$, Oxidation Reduction Potential (ORP) and COD were analyzed as per standard methods [55]. All the analyses in this study were repeated two or three times until concordant values were obtained.

After completion of the experimental study, the sand samples were collected from each column and surface morphology has been visualized by Scanning electron microscopy (SEM). Since SEM is important for high resolution visualization of bacterial biofilms [60]. In SEM, biofilm specimens are prepared by fixation, staining, drying and conductively coating prior to imaging under high vacuum [61]. Air dried samples were spread out on the sample mounted on aluminum stab sequenced by coating with a thin layer of gold under vacuum to increase the electron conduction and to increase the quality of the images [62]. The scanning electron imaging of sand samples of each column after leaching was done at 1-15 KV uses a microscope equipped with a filledemission cathode. The images were captured using SEM HITACHI (Model: S3000N) instrument with 100x and $500 \times$ magnification. 


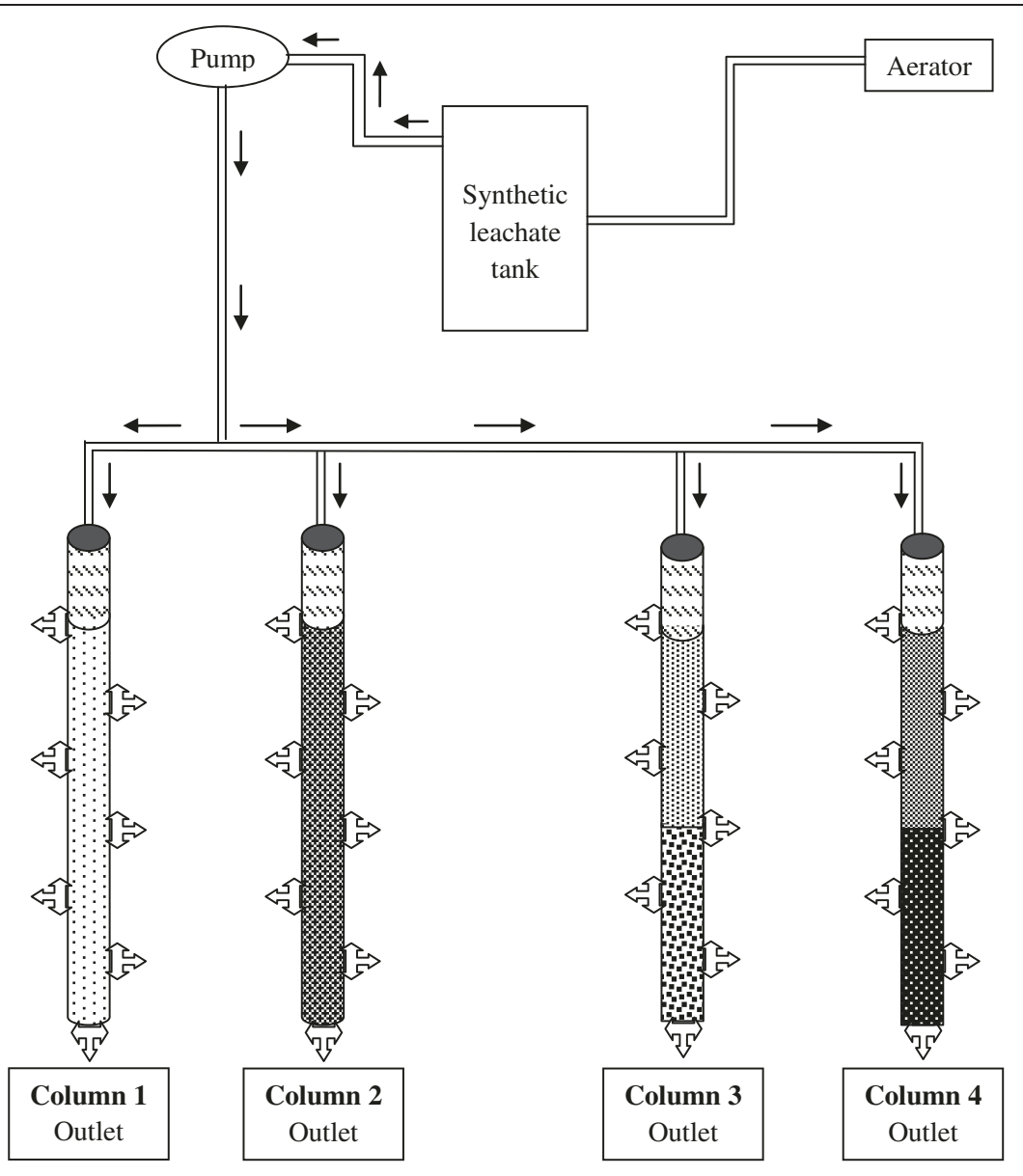

Column 1: mixed sand media without microbes (MSM); Column 2: mixed sand media with microbes (MSMM); Column 3: stratified sand media without microbes (SSM); Column 4: stratified sand media with microbes (SSMM)

Figure 1 Schematic representation of experimental setup.

\section{Results and discussion}

\section{Hydraulic conductivity (K)}

Four different sets of experiments were conducted for assessing changes in hydraulic conductivity permeated with a synthetic leachate solution. A constant head was held in each column throughout the experiment and flow rates were measured volumetrically at $24 \mathrm{~h}$ intervals. From these data, together with column geometry, hydraulic conductivity values were computed using Darcy's equation. The change in hydraulic conductivity as a function of time is shown in Figure 2. From the Figure 2, the discussions were made as follows: Initial hydraulic conductivity of the column was $2.03 \times 10^{-2} \mathrm{~cm} / \mathrm{s}$. After 45 days the hydraulic conductivity was decreased as $1.82 \times 10^{-2}$ $(\mathrm{MSM}) ; 2.31 \times 10^{-4}(\mathrm{MSMM}) ; 1.88 \times 10^{-2}(\mathrm{SSM}) ; 1.23 \times 10^{-3}$ (SSMM) in the columns. The blank column (MSM and SSM) tests resulted in a very less decrease in hydraulic conductivity when compared to the microbial inoculated

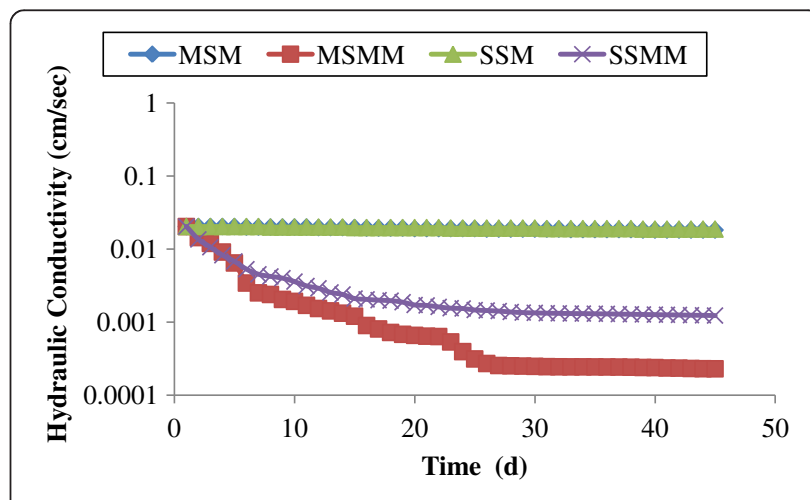

Figure 2 Changes in hydraulic conductivity as function of time. 
columns. The hydraulic conductivity in these columns was observed at almost similar as that of initial value for the first 15 days, later it started slight decrease due to precipitation of the permeated synthetic leachate [63].

After 45 days, the reduction in hydraulic conductivity was observed as 10\% in MSM and 7\% in SSM. The microbial inoculated column MSMM reduced hydraulic conductivity up to $98.88 \%$ during the 45 days of experimental operation. Within 2-3 days after microbial inoculation, a uniform biofilm of detectable thickness could be observed on the exposed edges of reactor media particles. Rapid decrease in $\mathrm{K}(68 \%)$ was attained in the first six days due to hasty microbial growth and its uniform biofilm thickness along the column. Mixed bio culture in the porous media and the uniform biofilm formation are responsible in hydraulic conductivity reduction from $24^{\text {th }}$ day onwards. The uniformity biofilm growth was happening due to the mixed proportion (70:30 mix) of porous sandy media; it allows the microbes to attach with the sand particles and further increases the biofilm growth. Hydraulic conductivity in the stratified media inoculated with microbes achieved a $93.94 \%$ reduction after 45 days of operation. For the first 6 days, $66 \%$ of reduction in K was observed due to the initial inoculums in the column. Subsequently, $90 \%$ of K reduction was achieved on 19th day, due to the biofilm formation. During the period between 27 and 45, the $\mathrm{K}$ value stabilized at 93\%. The higher reduction in hydraulic conductivity was achieved in MSMM column when compared to SSMM column.

\section{Effluent leachate composition changes}

Effluent leachate samples were collected from the outlet of the each column and tested for $\mathrm{pH}$, turbidity, TDS, ORP, Nitrates, Phosphate and COD concentrations on a daily basis. The influent $\mathrm{pH}$ was maintained between 6 and 6.05 during the experimental study. The change in $\mathrm{pH}$ as a function of time is shown in Figure 3. From the Figure 3, it is observed that the $\mathrm{pH}$ of the effluent slightly increased than the influent $\mathrm{pH}$ (ranged 6 - 7.01) in the blank columns (MSM, SSM) during the study. The

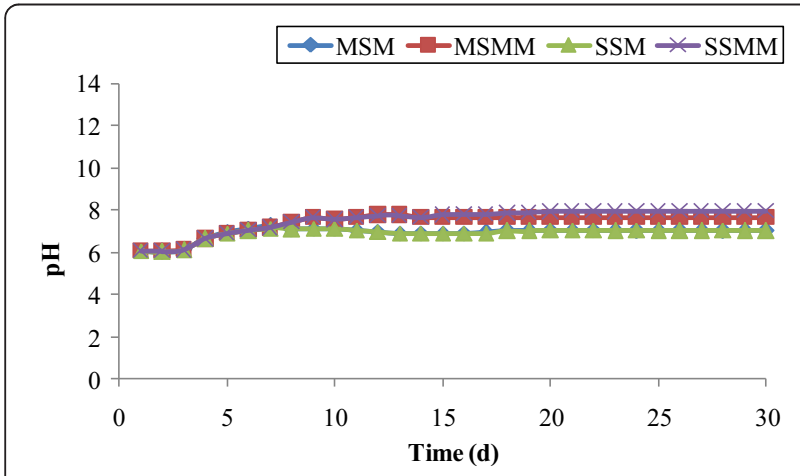

Figure 3 Changes in $\mathrm{pH}$ as function of time. effluent of blank column is in acidic nature, due to the presence of volatile acids in the supplied influent leachate. Similar effluent $\mathrm{pH}$ values were reported from column studies performed using synthetic leachate $[64,65]$. While in the microbial inoculated column, the $\mathrm{pH}$ range varied between 6 and 8. In the column MSMM, there was a gradual increase in effluent $\mathrm{pH}$ from 6 to 7.65 . Equally, in the column SSMM also, the value of $\mathrm{pH}$ gradually turns to alkaline. This may be attributed to the decrease in the concentration of free volatile acids due to anaerobic decomposition, as fatty acids can be partially ionized and contribute to higher $\mathrm{pH}$ values [66].

Turbidity is an indirect measure of biological activity, it consists of microorganisms and suspended and colloidal material generated by biological activity [67]. The initial turbidity (1 NTU) of the supplied influent synthetic leachate was stable throughout the experiment. The changes in the turbidity as a function of time for each column are shown in Figure 4. From the Figure 4, the initial turbidity is found to be constant for the first 5 days in blank columns (MSM, SSM) and, it increases slightly up to the maximum of $3 \mathrm{NTU}$ in the effluent during the study period. The turbidity levels were observed as significantly higher in effluent leachates in the microbial inoculated columns. The increase in the turbidity of the effluent leachate over time was indicative of biomass growth and accumulation in the sand-bed columns [58,67]. Higher turbidity value was observed as 16 NTU in MSMM and 9 NTU in SSMM due to the presence of microbial activity.

The total dissolved solids were measured in the effluent leachate on a daily basis from each column and it is shown in Figure 5. The TDS concentration of influent leachate was constantly maintained as $12900 \mathrm{mg} / \mathrm{L}$, throughout the experimental study. Very less reduction in TDS concentration was noted in the blank columns due to very less development of microorganisms. In the microbial columns, the mixed sand media allows producing extra polymeric substances in the gap formed between irregular sizes of grains. Thus, the developed microbes were completely utilised the organic nutrients supplied by

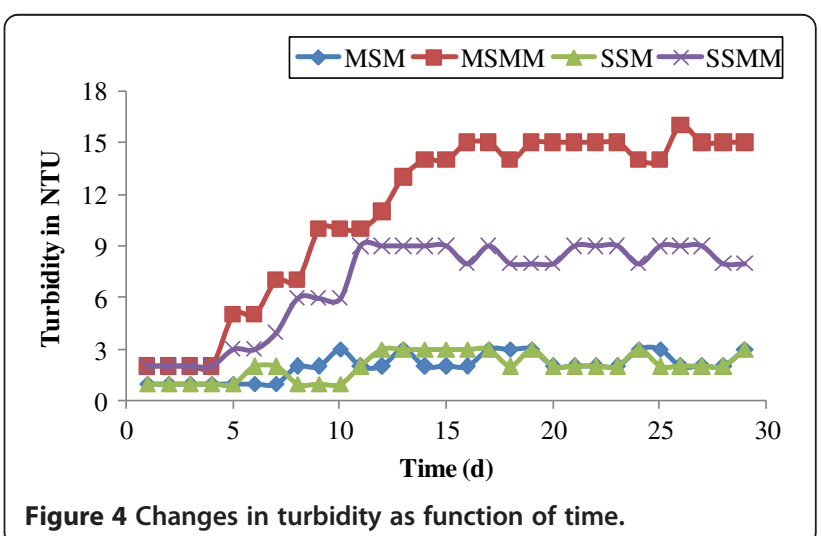




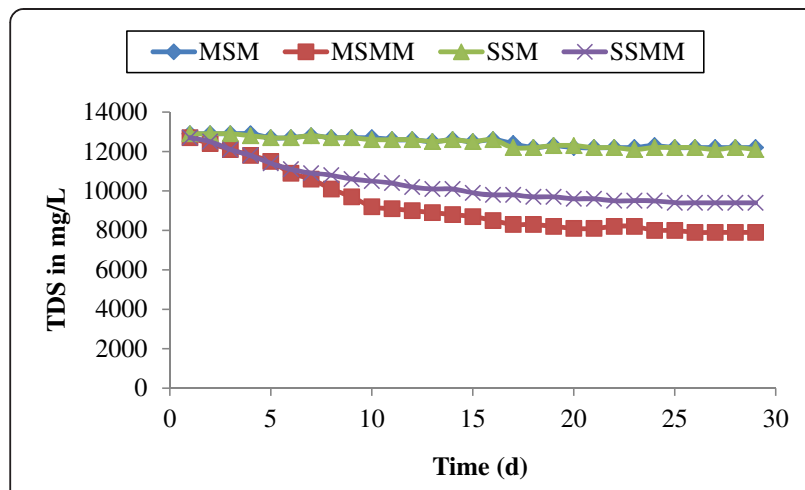

Figure 5 Changes in TDS as function of time.

the influent leachate and reduced more TDS concentration in the effluent leachate. The less reduction in TDS concentration of stratified column indicates that, less biofilm growth due to the uniformity sizes of coarse sand grains filled inside the column. There is a chance of a detachment of microbes in the coarse layer due to the more space between the sand grain particles.

ORP can be a useful parameter to check the digester performance since it measures the net value of all complex oxidation-reduction reactions within an aqueous environment. The measurement of ORP has been used in several instances as an environmental parameter in anaerobic digestion systems [68-71]. The changes in ORP were studied in the effluent leachate from each column, which is shown in Figure 6. From the Figure 6, the measured ORP values in the blank columns changes in the range between $594 \mathrm{mV}$ and $590 \mathrm{mV}$. In the column MSMM, the ORP value was observed clearly as $230 \mathrm{mV}$ at $18^{\text {th }}$ day and it was maintained throughout the experimental operation. The stable value of ORP indicates the constant growth of microorganisms and even distribution of biofilm layer inside the column [67,72]. In the stratified sand column (SSMM), the ORP value was decreased gradually from the initial value. At $15^{\text {th }}$ day of operation, the ORP changes from $+150 \mathrm{mV}$ to $-150 \mathrm{mV}$ due to anaerobic creation inside the column at $\mathrm{pH}$ 7.9. The report of Metcalf and

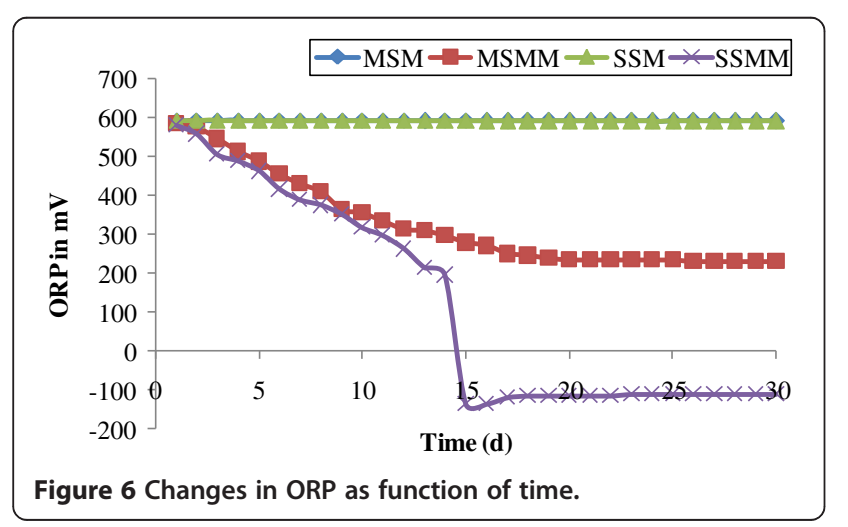

Eddy [73] clears that, the dramatic decrease in the ORP value $(+150 \mathrm{mV}$ to $-150 \mathrm{mV})$ at a single day, may be due to the dissolved oxygen concentration decline in the column. The ORP value was maintained as stable as $-150 \mathrm{mV}$ throughout the remaining days of experimental condition. This may be due to the initial stage of the propionic acid fermentation process in the column. An ORP of more than $-150 \mathrm{mV}$ always led to propionic acid-type fermentation at any $\mathrm{pH}$ and, at a $\mathrm{pH}$ of about 5.0, either propionic acid or butyric acid fermentation might occur depending on whether the ORP value is high or low $[74,75]$.

The changes in nitrate concentration as a function of time are shown in Figure 7. From the Figure 7, the nitrate concentration in the effluent leachate of the blank columns was observed at $3.3 \mathrm{mg} / \mathrm{L}$ and it was stable during the 30 days of experimental operation. The reduction of $1.1 \mathrm{mg} / \mathrm{L}$ was measured in the microbial column MSMM, due to continuous supply taken by the microbes. The stratified sand microbial column reduces the concentration to $2.1 \mathrm{mg} / \mathrm{L}$ at the end day of the experiment due to less growth of microbes. Similar results were reported by Yuliani et al. [43]. Likewise, the reduction of phosphates was observed more as $88 \%$ in the column MSMM (Figure 8) when compared to the column SSMM. There was a poor reduction in the blank columns from the influent leachate concentration.

The substrate concentration profile was estimated by measuring soluble COD concentrations in each column. Figure 9 shows the COD concentration profile for each column as a function of time. The initial COD concentration of $14000 \mathrm{mg} / \mathrm{L}$ was supplied during the experimental operation. In the blank columns (MSM, SSM), there was very little changes in the effluent leachate concentration with a $2 \%$ reduction $[64,65,76]$. In the case of microbial inoculated columns (MSMM, SSMM), the soluble COD (SCOD) reduction in the first 12 days was found to be rapid due to the growth of biofilm accumulation and its continuous intake of synthetic leachate.

Gradual reduction in SCOD was observed for the day 13 to 22 with less nutrient consumption by the microbes.

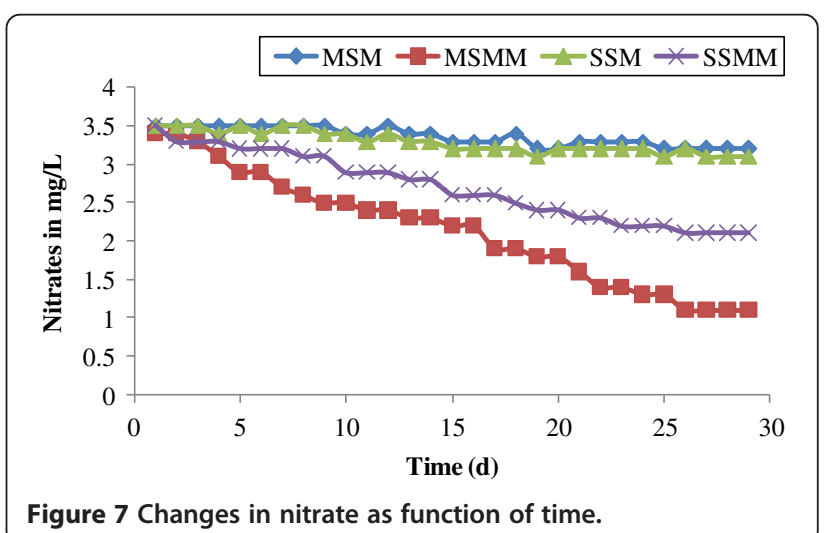




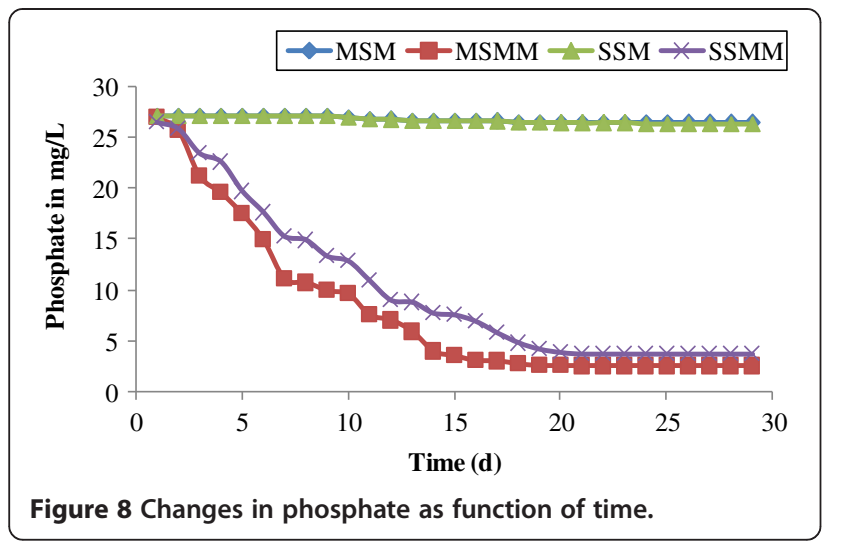

From the day, 23 to 30 the SCOD concentration turns to the steady state with stable consumption by the microbes. After 30 days of the experiment, the reduction in SCOD concentration in MSMM and SSMM was observed $76.19 \%$ and $54.21 \%$ respectively. The faster consumption of COD as time elapsed implies that microbial growth was continuous throughout the column depth as nutrient and electron acceptors were continuously provided [72,37,77]. When compared to MSMM column, SSMM column achieved a less reduction in the SCOD concentration in the effluent leachate. This may be due to less microbial growth in the coarse sand particles $(0.6 \mathrm{~mm})$ of the stratified column.

The reaction rate constant was derived from the pseudofirst-order kinetics plot and is reported in Table 4. From Table 4, the column MSMM shows the highest reaction rate of 0.062 days $^{-1}$ when compared to column SSMM $\left(\mathrm{k}=0.041\right.$ days $\left.^{-1}\right)$. This may be due the presence of more microbial attachment in the sand particles.

\section{Biofilm observation by SEM}

To understand the clogging phenomenon of biofilm, SEM images were observed for sand samples after the experimental operation. The scanning electron micrographs are presented in Figure 10. Figure 10(a-f) shows a 100 times enlarged SEM image of the sand surface samples to

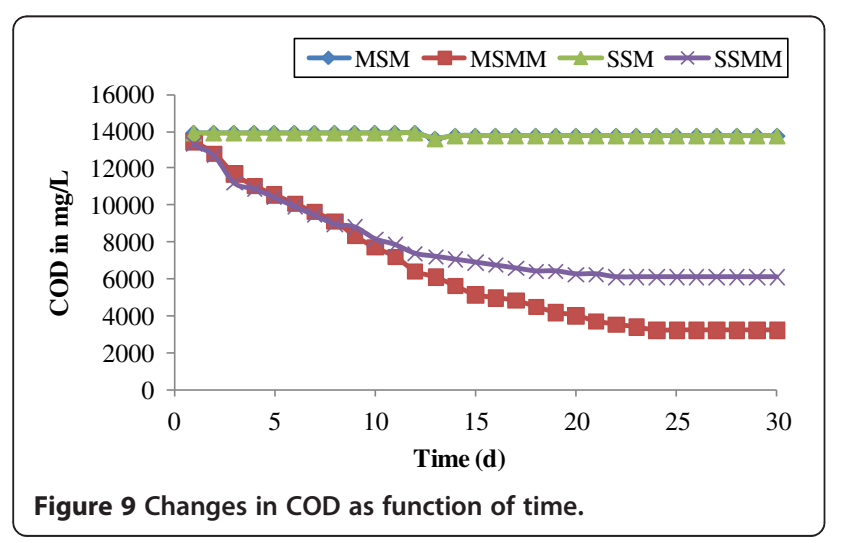

Table 4 Values of pseudo-first-order constant for different column conditions

\begin{tabular}{llll}
\hline S. No. & Column & Reaction rate constant $\mathbf{k}_{\mathbf{1}}\left(\right.$ day $\left.^{\mathbf{1}}\right)$ & $\mathbf{R}^{\mathbf{2}}$ \\
\hline 1. & MSM & 0.001 & 0.140 \\
2. & SSM & 0.001 & 0.140 \\
3. & MSMM & 0.062 & 0.993 \\
4. & SSMM & 0.041 & 0.835 \\
\hline
\end{tabular}

visualize the clogging attachment of an individual grain. Figure 10(a1-f1) shows a 500 times enlarged SEM image of sand surface samples to view the biofilm layer form. From the SEM images, the difference between the sand samples of blank columns and microbial inoculated columns can be seen clearly.

The observations from mixed sand media column were made as follows: Figure 10(a, a1) shows an image of the sand surface scan without clogging. The surface of the sand is smooth. Figure 10(b, b1) shows a picture of the surface scan of the sand after 45 days of clogging, which clearly shows the intensive growth of microbial films [34]. The inoculated bacterium forms several layers of mesh forms of biofilm between sand particles as well as on the sand surface. The formation mesh layers effectively clog the sand pore and result in hydraulic conductivity reduction [49].

The fine sand media were taken from the top of the stratified columns shows that, there was a slight formation of biofilm on the sand surface (Figure 10(c, c1)). This may be due to the less hydraulic conductivity of the fine sand particles used which allows the growth of microbes on the sand surface. Figure 10(d, d1) shows the, clear thick microbial layer on the surface of the sand grain.

The observations of coarse sand samples collected from the stratified column were discussed as follows: From the SEM images it can be seen that there was only a little difference between the blank columns and microbial inoculated columns. Figure 10(e, e1) shows a clear soft surface layer and it was found no microbial growth in the coarse sand media. A very thin layer of biofilm formation visualized on the coarse grain surface of the microbial column (Figure 10(f, f1)). The comparison of fine and coarse sand media concluded that, there was an appreciable formation of biofilm layer occurred only on the fine sand surface.

\section{Conclusion}

In this study, the concept of a biofilm accumulation in a sand column for controlling the leachate migration in the subsurface environment is reported. Synthetic leachate was supplied continuously for the microbial growth to measure the reduction in hydraulic conductivity and organic contaminants of the effluent leachate. Of the four 


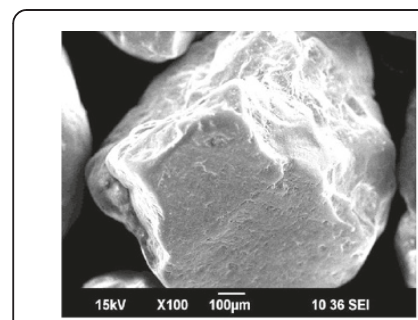

(a)

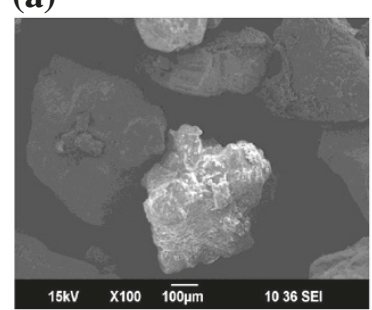

(b)

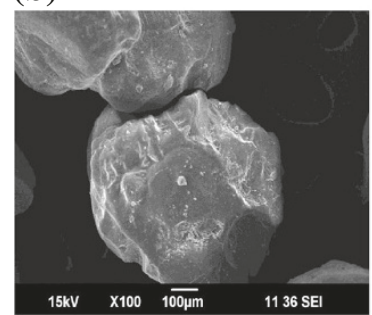

(c)

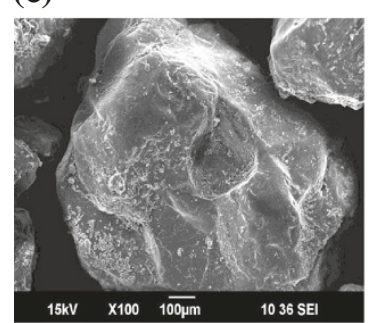

(d)

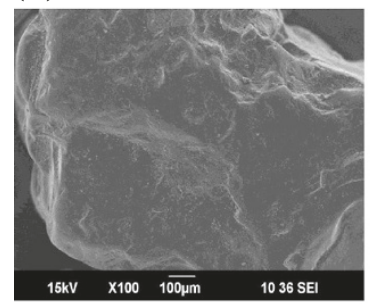

(e)

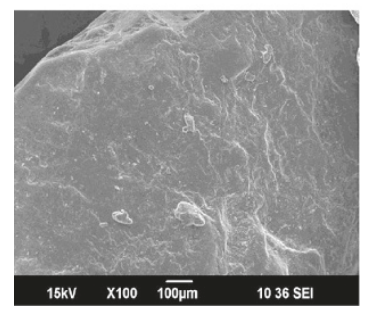

(f)

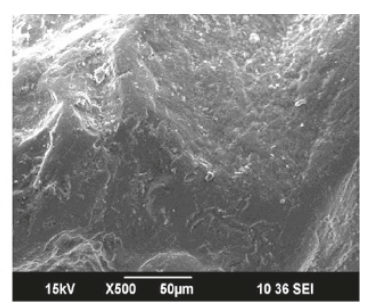

(a1)

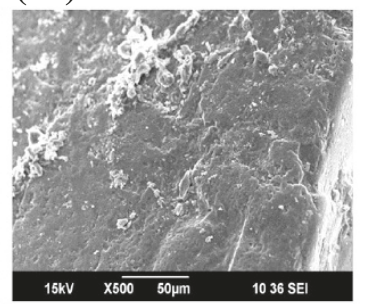

(b1)

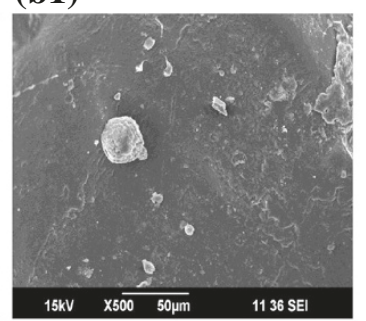

(c1)

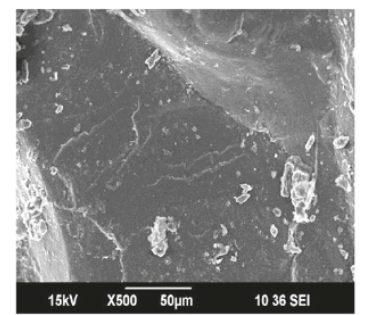

(d1)

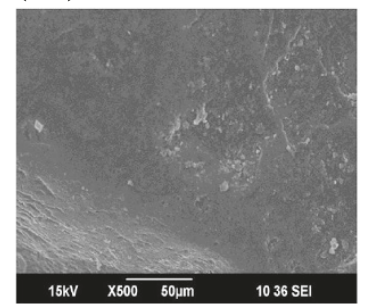

(e1)

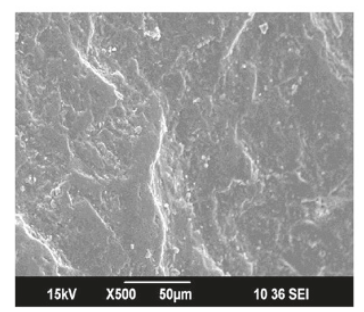

(f1)
Figure 10 SEM images of the sand grain surface sampled after 45 days of operation (100x: a - f; 500x: a1 - f1) a, a1. Mixed sand media without microbes; $\mathbf{b}, \mathbf{b} 1$. Mixed sand media with microbes; c, c1. Stratified fine media without microbes; $\mathbf{d}$, d1. Stratified fine media with microbes; e, e1. Stratified coarse media without microbes; $\mathbf{f}, \mathbf{f 1}$. Stratified coarse media with microbes.

different types of column experiment the following conclusions were made: With scanning electron microscope observation of biofilm, it can be observed that the sand column inoculated with bacteria formed several layers of the biofilm on the sand particles, which resulted in a hydraulic conductivity reduction. There was no appreciable change in the hydraulic conductivity and physicochemical parameters analyzed from the effluent of blank columns (MSM and SSM). The initial hydraulic conductivity of the column was $2.03 \times 10^{-2} \mathrm{~cm} / \mathrm{s}$. After 45 days of operation, $98.8 \%$ of hydraulic conductivity reduction was observed in the MSMM column with $2.31 \times 10^{-4} \mathrm{~cm} / \mathrm{s}$. The stratified microbial column (SSMM) reduces the hydraulic conductivity to $1.23 \times 10^{-3} \mathrm{~cm} / \mathrm{s}$ with $93.94 \%$. Hence, the mixed microbial sand column achieves the very good reduction in hydraulic conductivity.

The physico-chemical parameters were also implying the good results in the mixed microbial sand column among all four columns. A proper biological activity was observed from the turbidity and ORP results of MSMM column. Additionally, the reduction in nitrates and phosphates were also observed due to uniformity in the growth of microbes and continuous intake by microbes. In the case of the stratified microbial column, less reduction was taken place in the effluent leachate due to the less microbial growth formation in the coarse sand layer. There is a chance of a detachment of microbes in the coarse layer due to the more space between the sand grain particles.

The organic reduction of influent was estimated by SCOD concentration of each column. The column MSMM shows good reduction at $76.19 \%$, whereas in the column SSMM, 54.21\% reduction was achieved. This may be due to the continuous intake of organic substrate by the microorganisms. The pseudo-first-order constant value clearly indicates that the degradation of organic contaminants is due to heavy biofilm accumulation inside the sand column. From the overall results, the biobarrier formed by mixed sand media amended with microbes poses a suitable remedial measure for the reduction of hydraulic conductivity and organic contaminants in the leachate.

\section{Competing interests}

The authors declare that they have no competing interests.

\section{Authors' contributions}

This study is a part of the first author's Ph.D. thesis in the Environmental Engineering division. The first author carried out the experimental work under the guidance of Dr. RG. The manuscript has been referred by the Dr. RG and Dr. KM. All authors read and approved the final manuscript. 


\section{Acknowledgements}

The first author is extremely grateful to Dr. S. T. Ramesh, Associate Professor for his truly support to carry out this research. All the authors are thankful to National Institute of Technology, Tiruchirappalli, Tamil Nadu for carrying out this work in the Environmental Engineering laboratory.

Received: 30 July 2013 Accepted: 14 October 2014

Published online: 29 October 2014

\section{References}

1. Akoteyon IS, Mbata UA, Olalude GA: Investigation of heavy metal contamination in groundwater around landfill site in a typical sub-urban settlement in Alimosho lagos-nigeria. J App/ Sci Environ Sanitation 2011, 6(2):155-163.

2. Sabahi AE, Abdul Rahim S, Wan Zuhairi WY, Fadhl AN, Fares A: The Characteristics of Leachate and Groundwater Pollution at Municipal Solid Waste Landfill of Ibb City Yemen American. J Environ Sci 2009, 5(3):256-266.

3. Dong S, Liu B, Tang Z: Investigation and Modeling of the Environment Impact of Landfill Leachate on Groundwater Quality at Jiaxing Southern China. J Environ Technol Eng 2008, 1(1):23-30.

4. Landmeyer JE, Bradley PM: Effect of hydrologic and geochemical conditions on oxygen-enhanced bioremediation in a gasolinecontaminated aquifer. Bioremediation J 2003, 7:165-177.

5. Kanmani S, Gandhimathi R: Investigation of physicochemical characteristics and heavy metal distribution profile in groundwater system around the open dump site. App/ Water Sci 2013, 3:387-399.

6. Ahmed AM, Sulaiman WN: Evaluation of Groundwater and Soil Pollution in a Landfill Area Using Electrical Resistivity Imaging Survey. Environ Manag 2001, 28:655-663.

7. Fatta D, Papadopoulos A, Loizidou M: Evaluation of Groundwater and Soil Pollution in a Landfill Area Using Electrical Resistivity Imaging Survey. Environ Geochem Health 1999, 21:175-190.

8. Kjelsen P, Bjerg PL, Rugge K, Christensen TH, Pedersen JK: Characterization of an Old Municipal Landfill (Grindsted Denmark) as a Groundwater Pollution Source: Landfill Hydrology and Leachate Migration. Waste Manag Res 1998, 16:14-22.

9. Bjerg PL, Rugge K, Pedersen JK, Christensen TH: Distribution of Redox-Sensitive Groundwater Quality Parameters Downgradient of a Landfill (Grindsted Denmark). Environ Sci Technol 1995, 29:1387-1394.

10. Robinson H. Gronow J: Groundwater Protection in the UK: Assessment of the Landfill Leachate Source-Term. Inst Water Eng Manag 1992, 6:229-236

11. Cariera C, Masciopinto C: Assessment of Groundwater after Leachate Release from Landfills. Ann Chim 1998, 88:811-818.

12. Loizidou M, Kapetanios EG: Effect of Leachate from Landfills on Groundwater Quality. Sci Total Environ 1993, 128:69-81.

13. Gallorini M, Pesavento M, Profumo A, Riolo C: Analytical Related Problem in Metal and Trace Elements Determination in Industrial Waste Landfill Leachates. Sci Total Environ 1993, 133:285-298.

14. Khan R, Husain T, Khan HU, Khan SM, Hoda A: Municipal Solid Waste Management - A Case Study. Municipal Engin 1990, 7:109-116.

15. Kunkle GR, Shade JW: Monitoring Groundwater Quality near a Sanitary Landfill. Groundwater 1976, 14:11-20.

16. Van Ree CCDF, Weststrate FA, Meskers CG, Bremmer CN: Design aspects and permeability testing of natural clay and sand-bentonite liners. Geotechnique 1992, 4211:4956.

17. Daniel $\mathrm{DE}$, Benson $\mathrm{CH}$ : Water content-density criteria lbr compacted soil liners. J Geotech Eng ASCE 1990, 12:1811-1830.

18. Dickinson S, Brachman RWI: Deformations of a geosynthetic clay liner beneath a geomembrane wrinkle and coarse gravel. Geotext Geomembr 2006, 24:285-298.

19. Bouazza A: Geosynthetic clay liners. Geotext Geomembr 2002, 20:3-17.

20. Southen JM, Rowe RK: Modeling of Thermally Induced Desiccation of Geosynthetic Clay Liners. Geotext Geomembr 2005, 23(5):425-442.

21. Bouazza A, Van Impe WF, Van Den Broeck M: Hydraulic conductivity of a geosynthetic clay liner under various conditions. Proc Second Int Congr Environ Geotechnics, Osaka, Japan 1996, 1:453-458

22. Petrov RJ, Rowe RK, Quigley RM: Selected factors influencing GCL hydraulic conductivity. J Geotech Geoenviron 1997, 123(8):683-695.
23. Petrov RJ, Rowe RK, Quigley RM: Comparison of laboratory measured GCL hydraulic conductivity based on three permeameter types. Geotech Test $\lrcorner$ 1997, 20(1):49-62.

24. Fox PJ, Rowland MG, Scheite JR: Internal shear strength of three geosynthetic clay liners. J Geotech Geoenviron Eng ASCE 1998, 124(10):933-944.

25. Fox PJ, Triplett EJ, Kim RH, Olsta JT: Filed study of installation damage for geosynthetic clay liners. Geosynth Int 1998, 5(5):491-520.

26. Daniel DE, Koerner R, Bonaparte R, Landreth R, Carson D, Scranton H: Slope stability of geosynthetic clay liner test plots. J Geotech Geoenviron 1998, 124(7):628-637.

27. Lake CB, Rowe RK: Diffusion of sodium and chloride through geosynthetic clay liners. Geotext Geomembr 2000, 18(2-4):103-131.

28. Shackelford CD, Benson CH, Katsumi T, Edil TB, Lin L: Evaluating the hydraulic conductivity of GCLs permeated with nonstandard liquids. Geotext Geomembr 2000, 18(2-4):133-161.

29. Mazzieri F, Pasqualini E: Permeability of damaged geosynthetic clay liners. Geosynth Int 2000, 7(2):101-118.

30. Vangpaisal T, Bouazza A: Gas permeability of three needle punched geosynthetic clay liners. Newcastle, Australia: Proceedings of the Second ANZ Conference on Environmental Geotechnics: 2001.

31. Kemenade IV, Anderson WA, Scharer AM, Moo-Young M: Bioremediation enhancement of phenenthrene contaminated soils by chemical preoxidation. Hazard Wastes Hazard Mater 1995, 12:345-355.

32. Ress BB, Calvert PP, Pettigrew CA, Barlaz MA: Testing anaerobic biodegradability of polymers in a laboratory -scale simulated landfill. Environ Sci Technol 1998, 32:821-827.

33. Blowes DW, Ptacek CJ, Cherry JA, Gillham RW Robertson WD: Passive remediation of groundwater using in situ treatment curtains, Geoenvironment 2000, Characterization, Containment, Remediation, and Performance in Environmental Geotechnics. New York: American Society of Civil Engineers; 1995:1588-1607.

34. Zhong $X$, Wu Y: Bioclogging in porous media under continuous-flow condition. Environ Earth Sci 2012. doi:10.1007/s12665-012-1926-2.

35. Donlan MR: Biofilms: Microbial Life on Surfaces. Emerg Infect Dis 2002, 8(9):881-890.

36. Watnick P, Kotler R: Biofilm, city of microbes. J Bacteriol 2000 182:2675-2679.

37. Kim G, Lee S, Kim Y: Subsurface Biobarrier Formation by Microorganism Injection for Contaminant Plume Control. J Biosci Bioeng 2006, 101(2):142-148.

38. Taylor SW, Jaffe PR: Biofilm growth and the related changes in the physical properties of a porous-medium. 1. Experimental investigation. Res 1990, 26:2153-2159.

39. Cunningham AB, Characklis WG, Abedeen F, Crawford D: Influence of biofilm accumulation on porous porousmedia hydrodynamics. Environ Sci Technol 1991, 25:1305-1311.

40. Vandevivere P, Baveye P: Saturated hydraulic conductivity reduction caused by aerobic - bacteria in sand columns. Soil Sci Soc Am J 1992, $56: 1-13$

41. Ross N, Villemur R, Deschenes L, Samson R: Clogging of a limestone fracture by stimulating groundwater microbes. Water Res 2001, 35:2029-2037.

42. Seifert $D$, Engesgaard $P$ : Use of tracer tests to investigate changes in flow and transport properties due to bioclogging of porous media. J Contam Hydrol 2007, 93:58-71.

43. Yuliani E, Imai T, Higuchi T, Yamamoto K, Limantara LM: Nitrogen leaching and hydraulic conductivity Reduction by enhanced growth and biomass Accumulation of Lactobacillus sakei. Int J Acad Res 2011, 3:2.

44. Arnon S, Adar E, Ronen Z, Yakirevich A, Nativ R: Impact of microbial activity on the hydraulic properties of fractured chalk. J Contam Hydrol 2005, 76:315-336.

45. Seki K, Miyazaki T, Nakano M: Effects of microorganisms on hydraulic conductivity decrease in infiltration. Eur J Soil Sci 1998, 49:231-236.

46. Bielefeldt A, McEachern C, lllangasekare T: Hydrodynamic changes in sand due to biogrowth on naphthalene and decane. J Environ Eng 2002, 128(1):51-59.

47. Cusack FM, Singh S, Novosad J, Chmilar M, Blenkinsopp SA, Costerton JW: The use of ultramicrobacteria for selective plugging in oil recovery by waterflooding. Beijing, China: SPE Internaltional Meeting on Petroleum Engineering; 1992. 
48. Brough MJ, Al-Tabbaa A, Martin RJ: Active biofilm barriers for waste containment and bioremediation: laboratory assessment. Proc Int Symp In Situ and On-site Bioremediation, New Orleans, USA 1997, 4:233-238.

49. Kim G: Hydraulic conductivity change of bio-barrier formed in the subsurface by the adverse conditions including freeze-thaw cycles. Cold Reg Sci Technol 2004, 38:153-164.

50. IS 2720: Method of test for soil, Bureau of Indian Standards. 1987:Part 16.

51. Jeyasingh J, Philip L: Bio-remediation of chromium contaminated soil: Optimization of operating parameters under laboratory conditions. J Hazard Mater 2005, 118:113-120.

52. Jennings DA: Microbial transport in porous media. M.S. Thesis. Pullman, WA: Washington State University; 1994.

53. Madigan MT, Martinko J, Parker J: Brock biology of microorganisms. Englewood Cliffs: Prentice Hall; 2002.

54. Hrapovic L: Biodegradation of organic contaminants under diffusive transport through clayey soil. Ph.D. thesis. London, Ont: The University of Western Ontario; 2001.

55. APHA: Standard methods for the examination of water and wastewater. 17th edition. Washington DC: American Public Health Association; 1998

56. Skeen RS, Amos KS, Petersen JN: Influence of nitrate concentration on carbon tetrachloride transformation by a denitrifying microbial consortium. Water Res 1994, 28(12):2433-2438.

57. Clement TP, Peyton BM, Skeen RS, Jennings DA, Petersen JN: Microbial growth and transport in porous media under denitrification conditions: experiments and simulations. J Contam Hydrol 1997, 24:269-285.

58. Antizar-Ladislao B, Galil Nl: Biodegradation of 2, 4, 6-trichlorophenol and associated hydraulic conductivity reduction in sand-bed columns. Chemosphere 2006, 64:339-349.

59. ASTM D2434-68: Standard test method for permeability of granular soils (constant head). USA: ASTM International; 2006.

60. Walker JT, Verran J, Boyd RD, Percival S: Microscopy methods to investigate structure of potable water biofilms. Methods Enzymol 2001 337:243-255.

61. Kachlany SC, Levery SB, Kim JS, Reuhs BL, Lion LW, Ghiorse WC: Structure and carbohydrate analysis of the exopolysaccharide capsule of Pseudomonas putida G7. Environ Microbiol 2001, 3(12):774-784.

62. Kathiravan MN, Karthick R, Muthukumar K: Ex-situ bioremediation of $\mathrm{Cr}(\mathrm{VI})$ contaminated soil by Bacillus sp.: Batch and continuous studies. Chem Eng J 2011, 169:107-115.

63. Baveye P, Vandevivere P, Hoyle BL, DeLeo PC, De-Lozada DS: Environmental impact and mechanisms of the biological clogging of saturated soils and aquifer materials. Crit Rev Environ Sci Technol 1998, 28:123-191.

64. Rowe RK, VanGulck J, Millward SC: Biologically induced clogging of a granular medium permeated with synthetic leachate. J Environ Eng Sci 2002, 1:135-156.

65. VanGulcka JF, Kerry Rowe R: Evolution of clog formation with time in columns permeated with synthetic landfill leachate. J Contam Hydrol 2004, 75:115-139.

66. El-Fadel M, Bou-Zeid E, Chahine W, Alayli B: Temporal variation of leachate quality from pre-sorted and baled municipal solid waste with high organic and moisture content. Waste Manag 2002, 22:269-282.

67. Levine A, Harwood V, Cardoso A, Rhea L, Nayak B, Dodge B, Decker M, Dzama G, Jones L, Haller Edward M: Assessment of Biogeochemical Deposits in Landfill Drainage Systems. Florida Center for Solid and Hazardous Waste Management, University of South Florida, Integrative Biology Faculty and Staff Publications, Paper 275; 2005.

68. Blanc FC, Molof AH: Electrode potential monitoring and electrolytic control in anaerobic digestion. Water Pollut Control Fed 1973, 45(4):655-667.

69. Ishizaki A, Shibai $H$, Hirose $Y$ : Basic aspects of electrode potential change in submerged fermentation. Agricultral Biol Chem 1974, 38:2399-2406.

70. Colmenarejo MF, Sánchez E, Bustos A, García G, Borja R: A pilot-scale study of total volatile fatty acids production by anaerobic fermentation of sewage in fixed bed and suspended biomass reactors. Process Biochem 2004, 39(10):1257-1267.

71. Akin BS, Ugurlu A: Monitoring and control of biological nutrient removal in a Sequencing Batch Reactor. Process Biochem 2005, 40(8):2873-2878.

72. Ding A, Zhang Z, Fu J, Cheng L: Biological control of leachate from municipal landfills. Chemosphere 2001, 44:1-8.

73. Metcalf \& Eddy: Wastewater Engineering Treatment and Reuse. New Delhi: Tata McGraw-Hill Publishing Company Limited; 2007.
74. Gallert C, Winter J: Propionic acid accumulation and degradation during restart of a full-scale anaerobic biowaste digester. Bioresour Technol 2008, 99:170-178.

75. Wang L, Zhou Q, Li FT: Avoiding propionic acid accumulation in the anaerobic process for biohydrogen production. Biomass Bioenergy 2006, 30:177-182.

76. Armstrong MD: Laboratory program to study clogging in a leachate collection system. ME.Sc. thesis. London, Ont: The University of Western Ontario; 1998.

77. Wang $Z$, Charles B: An investigation into the microbial clogging potential of selected filter media as a result of biodegradation of a high-strength sulphate-rich alkaline leachate. Biodegradation 2006, 17:415-422.

doi:10.1186/s40201-014-0126-2

Cite this article as: Kanmani et al:: Bioclogging in porous media: influence in reduction of hydraulic conductivity and organic contaminants during synthetic leachate permeation. Journal of Environmental Health Science \& Engineering 2014 12:126.

\section{Submit your next manuscript to BioMed Central and take full advantage of:}

- Convenient online submission

- Thorough peer review

- No space constraints or color figure charges

- Immediate publication on acceptance

- Inclusion in PubMed, CAS, Scopus and Google Scholar

- Research which is freely available for redistribution

Submit your manuscript at www.biomedcentral.com/submit
C BioMed Central 